\title{
PANDANGAN MAHASISWA TERHADAP RADIKALISME (STUDI PENELITIAN DESKRIPTIF DI UIN MATARAM)
}

\author{
Husnul Hidayati \\ Universitas Islam Negeri (UIN) Mataram \\ Jl. Pendidikan No. 35 Mataram \\ Email: nanikpoenya@yahoo.com
}

\begin{abstract}
Abstrak: Dakwah, jihad, Islam memiliki korelasi parsial. Dakwah dalam pandangan setiap orang berbeda-beda, demikian pula jihad yang selalu identik dengan kekerasan. Seruan jihad dalam Islam bukanlah hal baru dalam Islam. Penelitian ini merupakan penelitian deskriptip kualitatif. Penelitian ini melibatkan mahasiswa sebagai informan. Hasil penelitian menunjukkan bahwa; (1) Dakwah sebaiknya dilakukan dengan mengedepankan kesantunan dan menghindari perilaku kekerasan karena sesungguhnya kemajemukan adalah bagian yang harus diutamakan; (2) Jihad sebagai bagian dari ajaran Islam jangan diartikan dalam makna yang sempit. Jihad sering diartikan sebagai upaya pembelaan agama pada saat perang dan banyak di dalilkan oleh pelaku teror. (3) Stigma bahwa Islam identik dengan kekerasan adalah sesat dan tidak dapat dibenarkan karena Islam sendiri bukanlah agama kekerasan, tetapi Islam sering dijadikan alat untuk meraih kekuasaan atau komoditas politik untuk menggaet kekuasaan.
\end{abstract}

\begin{abstract}
Da'wah, jihad, Islam has a partial correlation. Da'wah in of each person's view is different, jihad is also always synonymous with violence. The call for jihad in Islam is not new. This is a qualitative descriptive research. This research involves the university students as informants. The results showed that; (1) Da'wah should be done by promoting politeness and avoiding violent behavior because pluralism is a part that should take precedence; (2) Jihad as part of the Islamic teachings should not be interpreted in a narrow sense. Jihad is often interpreted as an effort to defend religion during the war and argued most of the time by the terror doer; (3) The stigma that Islam is synonymous with violence is heretical and can not be justified because Islam itself is not a violent religion, but Islam is often used as a tool to gain power or political commodities to gain power.
\end{abstract}

Kata Kunci: pandangan, mahasiswa, radikalisme

\section{PENDAHULUAN}

Indonesia adalah Negara bependuduk Muslim terbesar di dunia. Indonesia terdiri dari beribu pulau, suku, bahasa dan kebudayaan, atau lebih dikenal dengan Negara majemuk. Kemajemukan Bangsa Indonesia menjadi salah satu modal sosial yang baik dalam mengembangkan peradaban dan perekonomian. Potensi kemajemukan dapat menjadi keunggulan manakala dapat dimanfaatkan dan dikelola dengan baik, namun tidak menutup kemungkinan dapat menjadi sumber malapetaka manakala tidak dapat dipelihara dengan sebaik-baiknya.

Dalam pergaulan internasional, Indonesia seringkali dijadikan sebagai rujukan dunia tentang kerukunan antar umat beragama. Setiap orang berhak memilih agama dan 
beribadah menurut agamanya masing-masing. Umat agama lain tidak diperkenankan mengomentari agama orang lain karena bukan kompetensinya. Indonesia bahkan menjadi sumber rujukan tentang hakekat pluralisme yang dapat banyak ditiru oleh negara diberbagai belahan dunia.

Salah satu bukti pesatnya perkembangan peradaban modern yang pluralis di Indonesia adalah harmonisasi antar umat beragama. Hal ini sejalan dengan pasal 29 ayat 1 dan 2 UUD 1945 yang menyatakan bahwa; (1) Negara berdasarkan atas ketuhanan yang maha Esa; (2) Negara menjamin kemerdekaan tiap-tiap penduduk untuk memeluk agamanya masing-masing dan untuk beribadat menurut agamanya dan kepercayaannya itu". Ini artinya siapapun yang berada dinegara ini wajib menjunjung tinggi agama dan kepercayaannya sesuai dengan yang dianutnya.

Berangkat dari undang-undang tersebut, maka atas nama apapun tidak diperkenankan bagi agama apapun untuk menghina atau melakukan kekerasan dalam bentuk apapun terhadap agama lain. Kekerasan hanya akan memecahbelah persatuan bangsa dan akan menjauhkan masyarakat dari perilaku damai dalam bernegara. Kekerasan sebagai gerakan anti persatuan dan kebinekaan.

Radikalisme merupakan satu paham yang identik dengan kekerasan. Di Indonesia baru-baru ini telah muncul berbagai macam gerakan radikal baik atas nama agama maupun yang lainnya. Gerakan-gerakan dikatakan radikal terlihat dari aksi-aksi kekerasan yang dilakukan. Bahkan tidak mengakui keyakinan orang lain dan cenderung menganggap keyakinan sendiri yang paling benar. Tindakan lain yang juga menjadi salah satu sorotan aksi gerakan radikal adalah menghancurkan segala hal yang dianggap tidak sesuai dengan ajaran agama yang diyakininya, termasuk penghinaan terhadap kitab suci umat beragama.

Radikalisme tidak hanya terjadi pada tataran internasional, akan tetapi juga lokal (nasional). Radikalisme pada taraf internasional sebagai contohnya adalah merebaknya ideologisasi gerakan ISIS di Suriah dan Iraq. Gerakan ini menggoyahkan kedamaian dan perdamaian dunia. Gerakan ISIS bahkan sudah merambat di berbagai negara, terbukti dari baru-baru ini beberapa simpatisan ISIS yang ditangkap di Indonesia dan Turki. Dalam konteks lokal, radikalisme juga terjadi pada aksi pembantaian Kyai yang berkedok dukun santet sampai tragedi Poso (25 Desember 1998) dan tragedi Ambon (19 Januari 1999) dimana umat Islam menjadi korban ${ }^{1}$.

Peristiwa lainnya di tahun 2015 kekerasan terhadap anak di Nusa Tenggara Barat mengalami peningkatan dan tercatat 144 kasus sementara tahun 2016 menerima 255 laporan, sedangkan tahun 2017 dari awal januari sampai maret baru 9 laporan². Berdasarkan rentetan kasus kekerasan di atas bahwa persoalan kekerasan baik pada anak maupun menyangkut terorisme adalah masalah yang sangat serius. Aksi ini yang menjadi

\footnotetext{
${ }^{1}$ Nuraida, Gerakan Radikalisme Di Indonesia, Wardah: No. 23/ Th. XXII/Desember 2011, H. 154

${ }^{2}$ Republika.co.id diakses tanggal 24/3/2017 jam 7.09
} 
noda hitam bagi agama yang bernama Islam yang pada hakikatnya adalah agama yang rahmatan lilaalamin.

Berbagai macam peristiwa yang tidak dapat dilegalkan oleh akal dan pikiran dhaif manusia. Gerakan radikalisme disinyalir kerap terjadi karena lambannya pemerintah mengatasi kemaksiatan Diana pemerintah dianggap tidak konsisten menegakkan hukum yang cenderung tumpul ke atas dan tajam ke bawah. Hal ini juga karena ketidakberdayaan dari ormas-ormas Islam seperti Nahdlatul Ulama, Muhammadiyah dan Majelis Ulama Indonesia dalam memecahkan permasalahan umat atau menetral kondisi ummat ${ }^{3}$.

Atas kondisi di atas mendorong kelompok organisasi tertentu untuk membantu gerakan radikalisme atas nama persamaan ideologi. Organisasi yang tidak setuju dengan ideologi organisasi yang memiliki ideologi yang menghalalkan kekerasan atas nama kebaikan tidak akan terlibat sama sekali atas tindakan kekerasan. Namun organisasi semacam ini juga cenderung tidak mengarahkan kader organisasi namun menghimbau kader organisasi untuk tidak terlibat dalam agenda anarkisme. Kaitan dengan hal ini, maka gerakan-gerakan radikal muncul akibat ketidakpercayaan masyarakat terhadap kinerja aparat berwenang.

Pada dasarnya setiap agama mengakui bahwa agamanyalah yang paling benar dan agama orang lain salah. Sikap semacam ini akan memberi pengaruh yang baik manakala didorong semangat yang bersumber dari intrinsik setiap pemeluknya. Sikap beragama membutuhkan penghayatan dan aplikasinya sehingga ketaatan sebagai pemeluk agama akan dapat dijalankan dengan sebaik-baiknya sesuai dengan tuntunan ajaran agama tersebut. Lain halnya jika mengklaim bahwa agama kita saja yang paling benar, hal ini akan menimbulkan efek negatif yang sangat buruk karena dapat menganggap orang lain bukanlah pemeluk agama yang taat. Sebaiknya bagi siapapun dia " bagimu agamamu dan bagiku agamaku"4.

Pemaksaan agama atas agama orang lain sama dengan menghilangkan makna agama itu sendiri. Hal ini sebagaimana yang tertera dalam al-Qur'an surat al-Baqarah yang artinya sungguh tidak ada paksaan dalam beragama ${ }^{5}$. Pemaksaan agama akan menimbulkan konflik antar umat beragama yang berkepanjangan. Hal ini tidak menutup kemungkinan akan menimbulkan perselisihan antar umat beragama. Oleh karena itu dakwah dapat dilakukan dengan berbagai cara sesuai dengan kemampuan sendiri.

Agar dapat mencegah konflik komunal antar umat dibutuhkan dakwah yang dapat menenangkan setiap umat. Walisongo sebagai tokoh yang berjasa menyebarluaskan agama melakukan dakwah dengan cara persuasif, metode dakwah yang tidak menyinggung aliran kepercayaan umat lainnya, lentur dan akomodatif. Metode dakwah

\footnotetext{
${ }^{3}$ Afadlal, Islam dan Radikalisme di Indonesia, (Jakarta:LIPI, 2005), h. 2

${ }^{4}$ QS. Al-ikhlas

${ }^{5}$ QS. Al-Baqarah Ayat 256.
} 
walisongo juga tidak terlepas dari kulturisasi budaya setempat seperti adat istiadat dan karakter masyarakat setempat tanpa mengabaikan syariat ${ }^{6}$.

Mahasiswa sebagai generasi persiapan yang akan mewarnai perkembangan peradaban yang maju dan modern sejatinya membutuhkan pengetahuan yang komprehensif tentang radikal. Kampus bertugas mencetak kader-kader bangsa yang berkemajuan, beradab dan berdaya saing bebas. Di kampus mahasiswa dididik untuk bersikap nasionalis dan religius. Untuk menghindari mahasiswa dari pemikiran-pemikiran garis keras maka penting bagi mahasiswa dan kampus mengenalkan urgensi pengetahuan, pandangan mahasiswa tentang radikalisme, paling tidak pada tataran kampus.

Aktivitas-aktivitas mahasiswa tercermin dari perilaku dan kehidupannya selama dikampus. Kampus juga memiliki detektor yang dapat memantau perkembangan ideologi garis keras yang dapat merusak generasi muda bangsa yang lebih baik sehingga Mahasiswa harus benar-benar mengenali zamannya dengan segala kenyataannya. Aktivitas-aktivitas mahasiswa sedini mungkin dapat dikelola dengan baik agar pesanpesan moral dapat tersampaikan dengan baik dan menjadi kebiasaan mahasiswa.

Faktor ideologi adalah satu penyebab munculnya paham radikalisme di Indonesia. Perselingkungan mahasiswa dengan radikalisme di kampus dapat terjadi kapan saja, hal ini dapat terjadi dari berbagai hal diantaranya faktor komunikasi antar mahasiswa dan jaringan lainnya. Mahasiswa adalah salah satu masyarakat akademis yang dapat melenturkan keyakinan orang lain bahwa gerakan radikal hanya menjaring kaum tak berpendidikan, akan tetapi radikalisme dianggap juga telah menjangkiti mahasiswa.

Berdasarkan latar belakang masalah ini, penting untuk diketahui tentang bagaimana "Pandangana Mahasiswa Terhadap Radikalisme". Penelitian ini dilakukan dengan melibatkan mahasiswa di UIN Mataram sebagai sampelnya. Penelitian ini dalam rangka memetakan persepsi mahasiswa yang sebenarnya tentang radikalisme.

\section{HASIL DAN PEMBAHASAN}

\section{Pandangan Mahasiswa Tentang Dakwah Dengan Kekerasan.}

Perkembangan Islam di Indonesia sangatlah terpolarisasi. Polarisasi ini sudah terjadi sejak Indonesia merdeka. Sejak zaman pra kemerdekaan sudah sangat beragama, hal ini dibuktikan dengan munculnya beragam organisasi diantaranya NII, NU, Muhammadiyah, dan lainnya. Berkembangnya beragam organisasi juga juga memberikan warna yang berbeda terhadap ideologi dan faham keIslaman, pemikiran dan strategi gerakan yang berbeda dari pola pemahaman keagamaan yang dikembangkan oleh ormasormas Islam yang ada sebelumnya. Mereka berhaluan puritan, memiliki karakter yang lebih militan, radikal, konservatif dan eksklusif ${ }^{7}$.

\footnotetext{
${ }^{6}$ Sofwan, Ridin, "Para Wali Mengislamkan Tanah Jawa” dalam Merumuskan Kembali Interrelasi Islam-Jawa, (Yogyakarta: Gama Media, 2004) h. 6

${ }^{7}$ M. Imdadun rahmat, “Arus Baru Islam Radikal' (Jakarta: Erlangga, 2005), hlm. x.
} 
Perbedaan karakter dan polarisasi umat Islam memberikan panduan yang berbeda dalam melaksanakan aktivitas dakwah. Sebagian untuk sebagian yang lainnya menganggap bahwa karakter dari masing-masing organisasi keummatan sebagai pemicu gerakan-gerakan radikal. Pemikiran tersebut tidak dapat saja diterima tanpa ada kajian yang mendalam bahwa ideologi dan pemikiran beberapa ormas tergolong, radikal, konservatif dan eksklusif.

Untuk dapat memahaminya, perlu dipahami tentang konsep radikalisme. Secara sederhana radikalisme adalah pemikiran atau sikap yang ditandai oleh empat hal yang sekaligus menjadi karakteristiknya, yaitu: pertama, sikap tidak toleran dan tidak mau menghargai pendapat atau keyakinan orang lain. Kedua, sikap fanatik, yaitu selalu merasa benar sendiri dan menganggap orang lain salah. Ketiga, sikap eksklusif, yaitu membedakan diri dari kebiasaan orang kebanyakan. Keempat, sikap revolusioner, yaitu cenderung menggunakan kekerasan untuk mencapai tujuan ${ }^{8}$.

Sikap tidak toleran dan tidak mau menghargai pendapat atau keyakinan orang lain dapat mempengaruhi interaksi sosial masyarakat. sikap semacam ini cenderung menganggap pendapatnya yang paling benar dan pendapat yang lain salah, pendapatnya yang sahih rujukannya dan pendapat yang lain yang keliri merujuknya. Sikap-sikap semacam ini merusak perilaku toleransi antar umat beragama. Demikian pula sikap fanatik dan eksklusif yang selalu merasa benar sendiri pendapat lainnya salah serta berbeda dari orang kebanyakan.

Dampak paling nyata dari terjadinya radikalisme adalah terbentuknya politisasi di dalam agama, di mana agama memang sangat sensitif sifatnya, paling mudah membakar fanatisme, menjadi kipas paling ken-cang untuk melakukan berbagai tindakan yang sangat keras, baik di da-lam kehidupan sosial antar individu maupun kelompok, sehingga terbentuklah apa yang dinamakan kelompok Islam radikal ${ }^{9}$.

Pemikiran dan ideologi setiap polarisasi umat Islam memberikan strategi dakwah yang berbeda. Sebagian berdakwah dengan tradisionalitas yaitu membumikan budaya masyarakat sekitar dan dengan mengintegrasikan dengan konteks keIslaman atau dengan prinsip asas kebaruan dengan pemikiran yang modern. Dakwah semacam ini bukanlah hal yang harus dihindari melainkan di coba untuk dikaji bersama-sama efektivitasnya dalam menyampaikan pesan-pesan keummatan.

Akan tetapi, dakwah yang tidak dikehendaki adalah dakwah dengan kekerasan. Pemaksaan kehendak kepada orang lain untuk mengikuti ajaran, pemikiran maupun ideologinya. Dakwah semacam ini akan menimbulkan ketakutan bahkan dapat menghancurkan nilai-nilai perdamaian universal keummatan di bumi ini. Dakwah seperti ini harus dapat dihindari oleh masyarakat. bila strategi dakwah semacam ini menyebar

\footnotetext{
${ }^{8}$ Agil Asshofie, Radikalisme Gerakan Islam, http://agil-asshofie.blogspot.com/2011/10/radikalismegerakan-politik.html, diakses pada 10 April 2014.

${ }^{9}$ Emna Laisa, islam dan radikalisme, Islamuna,Volume 1 Nomor 1 Juni 2014. h. 3.
} 
luas ditengah kehidupan berbangsa dan bernegara, maka tak dapat dibayangkan apa yang akan terjadi pada kondisi negara ini yang mungkin dapat menimbulkan kekacauan dan permusuhan baik antar umat Islam atau Inter umat lainnya.

Bentuk-bentuk dakwah di atas harus dipahami oleh segenap masyarakat Indonesia termasuk agen perubahan yang bernama mahasiswa. Berdasarkan hasil wawancara bersama mahasiswa diperoleh beberapa pandangan tentang implementasi dakwah dengan kekerasan. Kekerasan dalam pandangannya bukanlah cara dakwah yang baik, mengedepankan kesantunan dalam menerima perbedaan serta mendiskusikan perbedaan lebih-lebh dalam konteks Negara berkemajemukan.

Kemajemukan merupakan hadiah bagi Negara berpenduduk Muslim terbesar bernama Indonesia. Terdiri dari beragam suku agama, ras dan warna kulit tetapi tetap dipersatukan oleh "Bhineka Tunggal Ika". Dalam arti bahwa apapun perbedaan ini tetap satu tujuan berlandaskan kepentingan bangsa dan Negara. Tidaklah benar memaksakan kehendak apapun terhadap warga Negara dengan atau kekerasan, lebih-lebih menyampaikan kebenaran Islam.

Islam adalah agama yang rahmatan lilaalamiin. Dakwah sebaiknya dilakukan untuk menyampaikan kebaikan dan merubah prilaku bermasyarakat. Dakwah dalam konteks ini dilakukan dari perasaan cinta terhadap agama, menjalankan syariat agama, dan mentaati perintah sang pencipta. Dakwah tidak dilakukan dengan atas dasar paksaan agar agama yang diyakininya dianut orang lain.

Bila dalam berdakwah terjadi pemaksaan kehendak maka tak dapat dipungkiri bahwa tergolong dalam gerakan Islam radikal. Radikalisme Islam adalah gerakan yang berpandangankolot dan sering menggunakan kekerasandalam mengajarkan keyakinan mereka $^{10}$.

Beberapa faktor penyebab utama seseoang menjadi radikal sebagai berikut; pertama,faktor pemahaman agama yang kurang tepat dalam hal ini. menyangkut isu pemurnian tauhid, taghyir al-munkar, relasi Muslim dan non-Muslim, pemaknaan doktrin jihad dan NKRI bukan negara Islam. Kedua adalah faktor politik. Faktor ini berhubungan dengan soal situasi politik global di mana sebagian umat Islam merasa berhak untuk menuntut balas atas ketidakadilan dan kesewenang-wenangan AS dan Eropa terhadap dunia Islam. Termasuk didalamnya adalah simpati dan solidaritas atas penderitaan yang dialami oleh dunia Islam (Palestina, Afghanistan, dan Irak) ${ }^{11}$.

Kedua faktor di atas memberikan penjelasan bahwa radikalisme terjadi dimana saja bahkan di setiap negara mengalami beragam organisasi radikal. Oleh karena itu dakwah sebaiknya dilakukan dengan memperhatikan kondisi dan situasi sosial masyarakat

\footnotetext{
${ }^{10}$ Nasution, Harun, Islam Rasional, (Bandung:Mizan, 1995), h. 124

${ }^{11} \mathrm{Abu}$ rokhmad, Pandangan Kiai Tentang Farhan Deradikalisasi Paham Islam Radikal Di Kota Semarang, Jurnal “Analisa”Volume 21 Nomor 01 Juni 2014 halaman 27-37.h. 29-30
} 
setempat. Dakwah dalam pandangan mahasiswa dapat dilakukan kapan saja dan dengan apa saja.

Teknologi dakwah menjadi alat penting dalam menjamin pesan-pesan keagamaan yang baik tersampaikan. Beberapa teknologi yang dapat digunakan diantaranya adalah what's up,facebook, instagram, tatap muka dan lain sebagainya.

Teknologi memang diakui memudahkan siapa saja penggunanya menyampaikan pikiran dalam sekejap mata. Teknologi juga berfungsi sebagai penyebar ideologi dan pemikiran tentang keagamaan. Teknologi sebagai media dakwah dalam pandangan mahasiswa dapat memberikan akselerasi informasi dengan satu ketikan saja. Berbeda halnya dengan ketika harus face to face, membutuhkan waktu yang lama dan harus menyusun daftar pertemuan.

Pada kondisi sekarang jarang bagi mahasiswa yang tidak memiliki teknologi. Mahasiswa sudah sering kali menggunakan android, sudah banyak browsing internet, menggunakan facebook dan lain sebagainya. Begitu mudah menyampaikan dakwah tanpa menggunakan kekerasan. Pemanfaatan teknologi informasi ini memiliki kelebihan dan kekeurangan. Dalam perspektif mahasiswa, banyak yang menulis status bernada dakwah namun tidak jelas sumber dan referensinya. Adapun kelebihannya dapat memudahkan dan mempraktiskan pendakwah dalam menyampaikan pesan dakwahnya.

Penggunaan kekerasan dalam menyampaikan dakwah tidak dilarang agama. Dalam hal ini beragam pandangan mahasiswa. Pertama, kekerasan bukanlah pilihan utama untuk menyampaikan kandungan isi Al-Qur'an dan Hadis. Islam mengajarkan cara-cara yang damai kepada umatnya dalam berhubungan dengan orang lain, termasuk dalam menyampaikan dakwah Islam sendiri. Cara yang ditempuh oleh Nabi Muhammad SAW dalam melakukan perubahan di masyarakat jauh dari cara-cara kekerasan, sebaliknya beliau lebih menggunakan pendekatan-pendekatan yang manusiawi. Ancaman-ancaman fisik yang diterima Nabi dan para sahabatnya ketika menyampaikan dakwah tidak dihadapi dengan kekuatan fisik, melainkan dengan cara-cara yang jauh dari sikap kekerasan $^{12}$.

Berdasarkan dalil di atas, dakwah yang baik dilakukan atas dasar cinta karena mengharapkan keridhoan Allah SWT. Dakwah yang dilandaskan atas keeeiiinginan bersama meraih surga Allah SWT. Dakwah yang dilandaskan pada rasa persaudaraan atas nama agama. Dakwah tidak boleh dilakukan pada orang yang sudah beragama dengan maksud mengajaknya masuk keagama kita. Hal ini juga telah tertuang surat Al-Ikhlas.

Kekerasan dalam menyampaikan dakwah tidak boleh dibudayakan. Kekerasan dapat menciptakan kericuhan dan kerancuan dalam menyampaikan pesan keagamaan. Setiap agama mengajar kehidupan yang cinta damai, beribadah menurut agama dan

12 Ahmad Baidowi, Prinsip Dakwah Tanpa Kekerasan dalam Al-Qur'an, Hermeneutik, Vol. 9, No.2, Desember 2015, h. 151 
keyakinannya masing-masing. Setiap agama juga berhak beribadah dalam keadaan nyaman. Hal ini sesuai dengan Pasal 29 UUD 1945 bahwa negara menjamin setiap warga negara untuk beribadah menurut agama dan keyakinannya masing-masing.

Pertanyaannya adalah dakwah yang seperti apa yang sesuai dengan prinsip-prinsip Islam dan keindonesiaan. Dalam konteks ini, dakwah dilakukan dengan senantiasa meyakinkan, menguatkan keyakinan dan mengingatkan antar pemeluk agama tentang ajaran agama yang dianutnya. Dakwah yang baik adalah dakwah yang sesuai dengan panutannya yaitu Rasulullah SAW. Dakwah dilakukan secara santun dan tidak menyinggung hati dan perasaan orang lain, baik yang seagama atau berbeda agama.

Dalam pandangan mahasiswa dakwah bagi sebagian kalangan dilakukan dengan santun dan sangat lembut. Namun sebagian lagi menggunakan kekerasan fisik. Dakwah yang menggunakan kekerasan perlu diakui bahwa tujuannya adalah untuk menghilangkan kemaksiatan seperti penjualan minuman keras, judi dan lain sebagainya. Dakwah seperti ini dapat mengganggu kepentingan umum, artinya pemaksaan untuk menghilangkan kemaksiatan dilakukan oleh sekelompok yang bukan pemerintah akan tetapi sekelompok organisasi masyarakat. beragam pandangan tentang dakwah semacam ini.

Dakwah dengan penggunaan fisik sebagai efek dari menjerakan prilaku nakal produsen kemaksiatan. Beberapa pernyataan informan bahwa dakwah ini terjadi karena pemerintah belum mampu menertibkan penguasa yang masih melaksanakan kegiatan penjualan miras dan perjudian. Dalam pendapatnya dakwah semacam ini dibolehkan manakala negara tidak hadir atau tidak sanggup menertibkannya.

Kondisi di atas memang miris terjadi karena dapat merusak generasi bangsa. Hal ini sejatinya harus dapat menetapkan siapa yang layak menyampaikan dakwah sebenarnya agar dapat menentramkan dan menyamankan kehidupan masyarakat. Dakwah dalam hal ini sebaiknya dilakukan oleh orang yang tepat. Dalam hal ini, dilakukan oleh ulama dan orang yang memiliki kompetensi dalam menyampaikan dakwah itu sendiri.

Penyampaian dakwah sebaiknya didampingi dengan aksi penegakan hukum. Umat Islam harus mampu menjaga toleransi antar umat beragama, tidak mengganggu ibadah atau ritual agama lain. Dakwah dilakukan dengan lisan yang baik dan dibuktikan dengan tindakan atau perilaku yang baik pula.

Secara umum perilaku kekerasan sering disebabkan oleh ketidakadilan ekonomi. Kekerasan biasanya disebabkan oleh keinginan manusia yang terlalu tinggi dengan kemampuan yang rendah. Dengan argumen ini, radikalisme muncul karena ekses kapitalisme yang menciptakan mereka yang tak memiliki akses pada sumber-sumber modal ${ }^{13}$. Minimnya akses menjadikan akidah cepat tergoyahkan, sehingga kebenaran sesuatu berdasarkan akal, wahyu, dan fitrah tidak lagi menimbulkan ketentraman di dalam jiwa orang yang meyakininya tidak lagi membekas. Padahal Allah dalam Al-Qur'an

${ }^{13}$ Ahmad Rizky Mardhatillah Umar, Melacak akar radikalisme Islam di Indonesia, Jurnal Ilmu Sosial dan Ilmu Politik Volume 14, Nomor 2, November 2010 (169-186) ISSN 1410-4946, h. 172 
mengatakan "orang-orang yang mengingat Allah sambil berdiri, duduk atau berbaring dan mereka memikirkan tentang penciptaan langit dan bumi (seraya berkata) "ya tuhan kami, tidaklah engkau menciptakan semua ini sia-sia; maha suci engkau lindungilah kami dari azab neraka ${ }^{14 "}$.

Dari penjelasan di atas dapat diketahui bahwa pengakuan hati, pengucapan lidah dan pengamalan anggota-anggota adalah tiga hal yang harus sejalan atau terpisah-pisah, maka akan menyebabkan seseorang menjadi fasiq dan munafiq ${ }^{15}$. Beberapa tujuan akidah Islam diantaranya adalah (1) memupuk dan mengembangkan potensi-potensi ketuhanan yanga ada sejak lahir, (2) memelihara manusia dari kemusrikan, (3) menghindarkan manusia dari pengaruh akal yang menyesatkan ${ }^{16}$.

Dasar kebahagiaan suatu Negara adalah pemerintahan yang berwibawa. Dengan kewibawaannya pemerintah mampu mendmaikan kelompok masyarakat-masyarakat yang berbeda pendapat dan keinginan yang kontradiktif. Dengan kekuasaan dan kekuatan pemerintah yang berwibawa mampu meredam dan menekan kelompok-kelompok masyarakat yang ingin berbuat jahat, makar dan permusuhan. Sebagian manusia mempunyai watak dan tabiat yang ingin menang sendiri, bersaing dengan cara yang tidak sehat, memaksakan keinginan kepada orang lain dengan cara kekerasan dan memusuhi orang lain yang menghalangi keinginannya. Mereka tidak akan sadar dan menahan diri dari watak buruknya itu, terkecuali dengan adanya kekuatan yang besar dan berwibawa ${ }^{17}$.

Keadilan merupakan salah satu dasar kebahagiaan dunia dan tiada ketertiban di dunia tanpa keadilan. Wajiblah sesorang berlaku adil pada dirinya sendiri, kemudia memperlkukan orang lain berlaku adil. Dengn tiga bentuk yaitu adil kepada bawahan, adil kepada atasan dan adil keada yang setara ${ }^{18}$.

\section{Pandangan Mahasiswa Tentang Radikalisme Atas Nama Jihad}

Salah satu persoalan serius bangsa kita saat ini adalah seberapa besar kita mampu menjaga negara ini dengan prinsip-prinsip pluralitas. Ditengah kemajemukan. Keberagaman menjadi kekhasan yang membuat negara-negara di dunia mengakui bahwa Indonesia adalah negara yang menghargai perbedaan. Dalam masyarakat majemuk terdapat perbedaan-perbedaan sosial, budaya, dan politik yang dikukuhkan sebagai hukum ataupun sebagai konvensi sosial yang membedakan mereka yang tergolong sebagai dominan yang menjadi lawan dari yang minoritas.

Islam sebagai agama mayoritas menjadi pengayom bagi agama-agama minoritas lainnya. konsep Islam sebagai rahmatan lil 'alamin yang bergema sejak 15 abad yang silam, hingga kini tak henti-hentinya dipertanyakan berbagai pihak, mengingat realitas

\footnotetext{
${ }^{14} \mathrm{QS}$ Surat Al-Imran ayat 191.

${ }^{15}$ Susiba dan Yasnel, Akidah Akhlak, (Pekan baru: CV Mutiara Pesisir Sumatra, 2014), h. 3.

${ }^{16}$ A. Zainuddin Dan M Jamhari, Akidah Dan Ibadah, (Bandung: Pustaka Setia, 1999), h. 50-51).

${ }^{17}$ Abu Alhasan Ali Al-Bashari Al-Mawardi, etika agama dan dunia, Bandung: CV Pustaka Setia, 2002: h. 99.

${ }^{18} \mathrm{Abu}$ Alhasan Ali Al-Bashari Al-Mawardi, etika agama dan dunia, (Bandung: CV Pustaka Setia, 2002), h. 109)
} 
yang berkembang justru menunjukkan umat Islam berada dalam kondisi yang memprihatinkan; miskin, terbelakang, dan lemah dalam segala hal ${ }^{19}$.

Dalam penerapan konsep-konsep Islam sebagai agama yang rahmatan lilaalamiin, perjuangan Islam mengajarkan konsep jihad. Islam datang membawa nilai-nilai kebaikan dan menganjurkan manusia agar menghiasi diri dengannya serta memerintahkan manusia agar memperjuangkan Islam hingga mengalahkan kebatilan ${ }^{20}$.

Proses memperjuangkan Islam hingga mengalahkan kebatilan sering kali diartikan dengan jihad dengan kekerasan. Islam memberikan keleluasaan untuk membela agama. Jihad sering salah diartikan oleh segelintir orang. Seolah-seolah jihad diperbolehkan oleh agama dan mempercayai bahwa kekerasan adalah bagian dari ajaran agama.

Bagi sebagian masyarakat jihad menjadi satu alat keyakinan tentang perjuangan membenarkan diri atas nama agama dan keyakinan. Fenomena perintah Jihad, misalnya. Disatu sisi, Islam seolah-olah membenarkan kekerasan. Dengan adanya doktrin jihad yang dipahami oleh sebagian ulama hanya sebagai tindakan mengangkat pedang terhadap musuh Islam, dan juga adanya perintah perang ${ }^{21}$.

Jihad dalam pandangan mahasiswa sering dikaitkan dengan terorisme. Ajaran Islam tentang jihad juga bagian dari mendukung gerakan terorisme. Padahal secara terminologi jihad diartikan sebagai pengarahan seluruh potensi dalam menangkis serangan musuh. Dalam hukum Islam, jihad mempunyai makna yang sangat luas, yaitu segala bentuk usaha maksimal untuk penerapan ajaran Islam dan pemberantasan kejahatan serta kezaliman, baik terhadap diri pribadi maupun terhadap masyarakat. Demikian jihad dalam pengertian umum. Adapun pengertian khusus, menurut Imam Syafi'i, yaitu memerangi kaum kafir untuk menegakkan Islam $^{22}$. terorisme yang ditujukan kepada penduduk sipil dapat berasal dari Pemerintah berupa state terror, meskipun tidak harus dengan penggunaan kekuatan senjata, tetapi juga dapat berupa tindakan Negara atau Pemerintah yang menyebabkan ketakutan yang luar biasa di kalangan penduduk sipil, baik hal itu berupa kebijakan Pemerintah, peraturan, ataupun perundang-undangan ${ }^{23}$.

Jihad dalam pandangan mahasiswa memang identik dengan peperangan. Namun dewasa ini peperangan dalam konteks permusuhan dalam pemanfaatan kekuatan fisik sudah jarang terjadi. Jihad tidak bisa diartikan secara sempit melainkan jihad diartikan dalam konteks yang lebih universal yaitu mempersiapkan diri menjadi manusia yang siap terhaadap perkembangan zaman untuk mengabdikan diri pada agama nusa dan bangsa. Hal ini senada dengan pandangan 2010, h. 21.

${ }^{19}$ H. Ma'mun Efendi Nur, Hukum Jihad dan Terorisme: Perspektif Al-Qur'an, Maslahah, Vol.1, No. 1, Juli

20 M. Quraish Shihab, wawasan Al-Qur'an, Tafsir Maudhu' I atas pelbagai persoalan umat, (Bandung: Mizan, 1996), jet ke 3, h. 501.

${ }^{21}$ H. Ma'mun Efendi Nur, Hukum Jihad dan Terorisme: Perspektif Al-Qur'an, Maslahah, Vol.1, No. 1, Juli 2010, h. 22.

${ }^{22}$ Dewan Redaksi. 1994. Ensiklopedi Islam 2, Fas-Kalangan. Jakarta: Ichtiar Baru van Hoeve.. h. 315

${ }^{23}$ Maulani, Z.A. dkk. 2005. Islam dan Terorisme: dari Minyak Hingga Hegemoni Amerika. Cet. ke1. Yogyakarta: UCY Press. 
Ali Imron bahwa konsep Jihad dalam pertumbuhannya mempunyai banyak makna dan cakupan mulai dari berjuang melawan hawa nafsu sampai mengangkat senjata ke medan peperangan. Namun, ada substansi Jihad yang bisa dibenarkan oleh hampir semua ulama, yaitu memahami Jihad sebagai satu seruan kepada agama yang hak. Jika kata Jihad dikaitkan dengan fisabilillah (di jalan Allah), maka Jihad fisabilillah berarti berjuang di jalan Allah. Jadi Jihad dalam arti di atas adalah perjuangan, dan perjuangan tersebut bisa dilakukan dengan tangan atau lisan untuk mempertahankan agama Allah $^{24}$.

Berjihad adalah pengorbanan kepada tuhan, membela agama Allah dan bersedia mengorbankan jiwa raga untuk perjuangan dan penegakan agama Allah. Dalam pandangan ini, jihad sebagai tingkatan terakhir dalam memperjuangkan agama Allah. Puncak pembelaan terhadap negara atau bangsa atas nama agama. Manakala negara dalam keadaan terancam, maka jihad sebagai Seruyan agama Islam wajib ditaati dan dipatuhi. Jihad tidak boleh dipaksakan dalam keadaan yang tidak sesuai dengan kondisi genting, tidak dapat diterapkan pada keadaan yang biasa-biasa saja. Jihad adalah Seruan suci yang pada akhirnya surga Allah yang akan menjadi balasannya.

Hal di atas juga pernah terjadi manakala Indonesia dijajah oleh Portugis, Jepang dan Belanda. Kondisi bangsa sangat memprihatinkan. Kondisi semacam ini dibolehkan melakukan jihad untuk membela negara dan wajib menegakkan dan memerdekakan diri prilaku perbudakan. Akan tetapi, saat ini kondisi semacam ini tidaklah terjadi sehingga jihad yang dibutuhkan adalah berjihad dengan harta, artinya manakala memiliki kelebihan maka wajib baginya untuk membagikan sebagian hartanya bagi orang yang membutuhkan. Itu juga merupakan bagian dari jihad itu sendiri.

Jihad diartikan sesuai dengan kondisi dan profesi masyarakat. Pandangan sebagian mahasiswa bahwa jihad sebaiknya diorientasikan pada perbaikan kualitas pemeluk agama. Atau jihad dapat diartikan sebagai upaya untuk menegakkan aturan yang pro rakyat dengan kebijakan-kebijakan yang produktif, memberikan teguran kepada pemerintah agar dapat melaksanakan pemerintahan yang transparan dan dapat terkendali dengan baik. Jihad di sini berguna untuk meningkatkan kualitas warga negara dengan melakukan perubahan-perubahan kerah berkemajuan melalui peningkatan keterampilan dengan sebaik-baiknya.

Demikian pandangan-pandangan mahasiswa tentang jihad, namun bagaimana pandangan tentang jihad melawan diri sendiri. Jihad dalam konteks ini merupakan jihad melawan keinginan terbesar dalam diri kita seperti pemuasan diri secara material biologis dan lain sebagainya. Jihad seperti ini sesuai dengan hadis yang menyatakan bahwa jihad terbesar (jihad akbar) adalah: "jihâd al-nafs (jihad melawan hawa nafsu)"Rasulullah SAW

${ }^{24}$ Ali Imron, Konsep Jihad Dan Implementasinya Terhadap Pembelajaran Di Madrasah (Studi Kasus Pada Madrasah Se-Kecamatan Karangawen, Kabupaten Demak 2014), Tesis STAIN Salatiga, Diakses Tanggal 03/07/2017 Jam 14.00 WITA 
telah bersabda : Jihad itu ada dua macam, dan yang paling utama adalah jihâdal-nafs (jihad melawan hawa nafsu). ${ }^{25}$ " .

Jihad memiliki porsi dengan situasi tertentu dapat diterapkan, namun pada prakteknya, jihad dewasa ini dijadikan sebagai panduan dan pegangan bagi teroris untuk melawan pemerintah dan ketidakadilan. Kaitan dengan ini mahasiswa memiliki pandangan yang beragam. Penyebab dari banyaknya terjemahan jihad disebabkan oleh banyak hal diantaranya adalah keinginan untuk mendirikan negara Islam, melaksanakan sistem pemerintahan berlandaskan al-Qur'an dan sunah nabi dan lain sebagainya.

Adanya keinginan-keinginan di atas menyebabkan munculnya gerakan radikal yang mengatasnamakan jihad. Hal ini memunculkan berbagai faksi diantaranya yang mendukung demokrasi dan anti demokrasi. Demokrasi dianggap sebagai produk barat. Sedangkan negara Islam adalah negara yang berbasis pada kitab suci sehingga tidak ada Siantar umat manusia Indonesia yang kaya makin kaya dan miskin makin miskin, karena negara menganut sistem kapitalis. Sementara kalau negara dikelola dengan sistem Islam maka tidak akan terjadi ketimpangan yang begitu jauh antar warga negara.

Merebaknya gerakan Islam radikal menimbulkan beragam tafsir diantaranya adalah tentang pola rekrutmen para jihadist. Tentu ini menjadi pertanyaan yang membutuhkan jawaban. Menurut mahasiswa bahwa kaderisasi jihadis menyasar pada kriteria lemah imannya, rendah pendidikannnya, dan keras pemikirannya, selanjutnya adalah doktrinisasi.

Oleh karena itu untuk mencegah dan memproteksi menyebarnya gerakan Islam radikal maka pemerintah sebagai wakil negara perlu mempersiapkan fasilitas pendidikan yang memadai, menguatkan karakter dan pandangan Islam melalui optimalisasi peran ulama, menguatkan pendidikan karakter di sekolah-sekolah, kampus dan majelis taklim.

Penyebab berikutnya adalah kemiskinan. Kondisi miskin membuat setiap orang buta akan dirinya. Hal ini menyebabkan ia mudah untuk dipengaruhi dengan iming-imingiming tertentu. Kemiskinan disebabkan oleh banyak hal diantaranya kebanyakan sikap berdiam diri, enggan, tidak mau berusaha dan kurang bergairah untuk menggali sumber daya $a^{26}{ }^{26}$. Kemiskinan bukan bermula dari struktur sosial, tetapi berasal dari karakteristik khas orang-orang miskin. Orang-orang miskin menjadi miskin karena ia tidak mau bekerja keras untuk melakukan perubahan pada dirinya, tidak hemat, sedikit mempunyai rencana, kurang mempunyai jiwa wiraswasta, kurang fasilitas, sulit memunculkan hasrat berprestasi dan sebagainya ${ }^{27}$.

Selain kemiskinan, pencitraan tentang Islam yang radikal adalah bagian dari asumsi Barat tentang Islam yang radikal. Sebenarnya pencitraan Barat yang buruk

\footnotetext{
${ }^{25} \mathrm{Abu}$ Abdullah Muhammad bin 'Ali bin al-Husain al-Hakim atTirmidzi, Nawâdir al - Ushûl Fî Ahâdîts ar - Rasûl Shallallâhu 'Alaihi Wa Sallam, juz IV, hal. 56))

26 Sihab dalam Kamarudin, Jihad Dalam Perspektif Hadis, STAIN Datokarama Palu, Jl. Diponegoro 23 Palu,h. 107

${ }^{27}$ Ibid,h. 107.
} 
terhadap Islam tersebut tidak hanya terjadi pasca tragedi WTC saja. Akan tetapi jauh sebelum itu, pencintraan negatif yang dialamatkan kepada Islam telah terjadi, seperti sejak Perang Salib. Pencitraan negatif itu lantas diejawantahkan dan dikristalkan dalam orientalis/Islamolog $)^{28}$.

Pencitraan barat tentang Islam menjadikan umat Islam yang radikal membenci barat dan sekutunya. Sekutu yang dimaksud selain itu diartikan sebagai pendukung barat. Sehingga menyebabkan terjadinya teror dimana-mana. Teror yang menyebabkan ketakutan dan keresahan dimana-mana.

Beragam metode teror yang sering terjadi di Indonesia diantaranya, Bom Panci, perampokan, penusukan dan ancaman terhadap keamanan negara. Teror dapat terjadi pada siapa saja yang mendukung pernyataan barat. Oleh karena itu, sinergisitas ulama dan umara dinegeri ini harus saling bahu membahu, bekerjasama memberantas negara dari doktrinisasi aliran-aliran yang dapat mengganggu keamanan dan ketentraman negeri ini. Upaya deradikalisasi perlu dibudayakan demikian pula pemerintah semaksimal mungkin menghadirkan pemerintahan yang berkeadilan.

\section{Pandangan Mahasiswa Tentang Radikalisme Identik Dengan Agama Islam.}

Islam sebagai agama yang fitrah mengajarkan amalan muamalah dan ibadah sesuai dengan ketentuan dan ajaran kitab suci al-Qur'an. Dalam melaksanakan ibadah dan muamalah dengan segala atributnya, Islam sering dijadikan sebagai agama yang membolehkan perilaku kekerasan, padahal perilaku kekerasan hanya dapat dilakukan pada batasan tertent yan tidak dapat ditolerir oleh prinisip agama.

Islam dalam pandagan mahasiswa dijadikan sebagai batas yang membatasi perilaku manusia dari anti kebebasan yang dikontraskan dengan proyeksi barat yang menghalalkan kebebasan dinamisme, demokrasi, kesetaraan dan rasionalitas. Sehingga kebanyakan mereka melakukan dekonstruksi terhadap kitab suci agama Islam untuk menemukan kesalahan dari tekstual kitab suci itu sendiri.

Dekonstruksi kitab suci juga tidak terlepas dari Islam sebagai agama dan politik. Sebagaimana pandangan Quintan dalam Book review Noerhadi Hasan bahwa Islam politik sebenarnya merupakan gejala politik-keagamaanyang tak bisa dipisahkan dari konteks power struggle. Di dalamnya terjadiperkawinan yang sempurna antara politik dan agama. Motif-motifpolitik yang berupaya menempatkan Islam dalam lingkar kekuasaannegara, sebagai sistem yang mengatur semua aspek kehidupan,termasuk norma hukum, sosial-budaya, sistem ekonomi, dan tatahubungan internasional, mendapatkan legitimasinya dalam bahasabahasaagama ${ }^{29}$.

\footnotetext{
${ }^{28}$ DadanRusmana, al Qur'an dan Hegemoni Wacana Islamologi Barat, cet. I.,(Bandung: Pustaka Setia, 2006), hlm.58-60.

${ }^{29}$ Quintan Wiktorowicz, Islamic Activism, A Social Movement TheoryApproach, Bloomington dan Indianapolis, IndianaUniversity Press, 2004, Book review oleh Noorhaidi Hasan
} 
Menurut mahasiswa, gerakan radikal di Indonesia sering diidentikkan dengan pemikiran dan pandangan suatu agama, terutama Agama Islam. Sementara kekerasan yang dilakukan oleh masyarakat yang non-agama Islam sering tidak dianggap sebagai radikalisme, padahal kekerasan menyamai kondisi lainnya seperti halnya pembakaran masjid di Papua. Hal ini menyebabkan adanya prasangka yang kurang baik terhadap pemerintah yang memberikan perlakuan tak seimbang antara Muslim dan non-Muslim.

Kondisi lainnya bahwa Islam dipandang sebagai pemicu gerakan radikal karena disebabkan oleh aliran jihadnya. Jihad yang dalam pandangan kami sebuah keyakinan untuk melakukan kekerasan. Padahal pada prakteknya Islam adalah agama yang rahmah, cinta damai, dan anti terhadap kekerasan. Jadi peristiwa ini sebagai bagian dari kampanye orang-orang yang anti Islam terhadap ajaran Islam itu sendiri.

Kekerasan atas nama agama tidak dibenarkan. Tak terkecuali di Indonesia - yang dikenal sebagai bangsa religius, santun dan ramah-praktek-praktek kekerasan atas nama agama kerap terjadi. Peristiwa terakhir yang terjadi adalah tragedi di Cikeusik Banten, Temanggung Jawa Tengah dan Penyerangan Pesantren Islam di Pasuruan Jawa Timur serta aksi-aksi kekerasan berbasis agama lainnya ${ }^{30}$.

Seperti yang sudah dijelaskan pada pembahasan sebelumnya bahwa kekerasan terjadi karena minimnya pemahaman agama seseorang atau konsumsi bacaannya tentang jihad. Padahal Al-Qur' an sebagai rujukan pertama umat Islam tidak mengalami perubahan secara tersurat atau tersirat. Dari itu apapun ajaran tentang Islam berdsarkan Al-Qur'an adalah ajaran Allah SWT. Sehingga Seruyan jihad sebagai perilaku yang kejam, jahat dan perusak tatanan kehidupan bermasyarakat adalah hal yang tidak benar.

Al-Qur'an yang dipandang sebagai kitab suci umat Islam tidak lepas dari berbagai macam penafsiran. Kondisi teks keagamaan Islam yang multi tafsir seakan-akan memberi peluang kepada siapa saja yang mempunyai kepentingan untuk menafsirkan sesuai dengan nilai kepentingannya. Tentu saja interpretasi teks keagamaan yang dilakukan disesuaikan dengan kebutuhan mereka masing-masing. Sebagaimana yang dilakukan oleh sebagian kelompok yang menafsirkan ayat-ayat Al-Qur'an sebagai alat untuk melegalkan aksi-aksi kekerasan atas nama agama. Teks dipasung untuk menggerakkan tindakan-tindakan kekerasan atas nama Tuhan. Bahkan dengan hasil penafsiran yang sedemikian, sebagian kelompok semacam ini kemudian bersedia mengorbankan apa saja atas nama agama; dari harta sampai jiwa. Demi agama pula manusia bersedia melakukan hal-hal yang irasional maupun hal-hal yang dinilai tidak sehat menurut orang lain ${ }^{31}$.

Dalam pandangan mahasiswa, dewasa ini banyak yang menafsirkan ayat-ayat AlQur'an berdasarkan kepentingan dirinya masing-masing. Kepentingan di sini dalam arti politik, sosial, ekonomi dan budaya. Namun penafsiran yang baik adalah dengan

\footnotetext{
${ }^{30}$ Junaidi Abdillah, Radikalisme Agama: Dekonstruksi Tafsir Ayat-Ayat "Kekerasan" Dalam AlQur'an, Volume 8, Nomor 2, Desember 2014 h. 282

${ }^{31}$ Ibid, h. 286
} 
menjelaskan asbabun nuzul ayat yang dikontekstasikan dengan kondisi terkini melalui ijtihad. Tidak semata-mata mengedepankan kepentingannya atau golongannya.

Perbedaan penafsiran tentang kitab suci bukan hanya hari ini saja terjadi. Aliran dalam Islam berkembang sejak lama. Pada zaman kekhalifahan Ali saja, begitu banyak umat Islam yang memiliki aliran yang berbeda. Perbedaan ini condong kepada akidah dan keimanannya. Dari sekian banyak aliran dalam Islam, beberapa aliran memiliki pemikiran yang keras diantaranya khawarij. Jadi atas nama apapun maka pelaku kekerasan tidak boleh dibiarkan berkembang di bumi Indonesia.

Terorisme dan kekerasan adalah kejahatan. Setiap kejahatan harus dibumi hanguskan. Jangan melihat sebuah kasus agama tertentu sebagai kekerasan, akan tetapi agama apapun juga yang menghalalkan kekerasan harus diamankan. Terorisme menebar ketakutan dimana-mana. Dan perlu dihindari agar pelabelan teroris sebagai bagian dari ajaran Islam harus dapat dihindari.

Isu-isu radikalisme agama dan kekerasan juga sering dijadikan sebagai komoditas politik. Dalam pandangan mahasiswa bahwa kekerasan sebagia bagian dari jargon politik. Demikian pula radikalisme agama tidak akan terlepas dari kepentingan politik karena secara historis sosiologis, isu ini menjadi isu yang hangat dibicarakan di dunia global. Isu ini sangat sensitif untuk mengangkat atau menurunkan elektabilitas kandidat.

Sebagai komoditas politik, isu radikalisme tidak hanya terjadi di Indonesia, bahkan Sibayak negara seperti halnya Amerika Serikat. Isu ini bagian dari pembangunan peradaban sebuah negara dan salah satu cara untuk membantu masyarakat memahami gerakan radikalisme adalah melalui lembaga politik itu sendiri.

Mahasiswa sebagai agen perubahan (agen of change) tentu mengkaji lebih mendalam tentang gerakan radikal itu sendiri. Lalu apakah semua gerakan Islam seperti aksi bela Islam untuk memenjarakan penghina agama juga bagian dari kekerasan. Kaitan dengan hal ini mahasiswa memiliki komentar masing-masing. Mahasiswa sebagian berpendapat bahwa aksi bela Islam adalah aksi solidaritas antar sesama pemeluk agama yang tidak menginginkan kitab sucinya diolok-olok oleh agama lainnya dan sebagian lagi berpendapat bahwa aksi ini merupakan aksi yang ditunggangi oleh kepentingan politik, karena aksi ini terjadi saat berlangsungnya gelaran pilkada di DKI Jakarta.Bagi sebagian mahasiswa justru memiliki pandangan berbeda bahwa aksi ini pada dasarnya adalah gerakan Islam radikal karena dikomandoi oleh orang yang selama ini memiliki Track record yang mengamini kekerasan.

\section{SIMPULAN}

Berdasarkan hasil pembahasan di atas dapat disimpulkan tiga hal yaitu: (1) Dakwah dapat dilakukan secara tradisional dan modern. Secara tradisional dilakukan dengan tatap muka dan secara modern dilakukan dengan menggunakan media seperti facebook, WA dan lain sebagainya. Pemikiran dan ideologi masyarakat dapat membentuk polarisasi umat sehingga membutuhkan strategi dakwah yang berbeda. Dakwah dilakukan 
dengan mengedepankan kesantunan dan menghindari perilaku kekerasan karena sesungguhnya kemajemukan adalah bagian yang harus diutamakan; (2) Jihad sebagai bagian dari ajaran Islam jangan diartikan dalam makna yang sempit. Jihad sering diartikan sebagai upaya pembelaan agama pada saat perang dan banyak di dalilkan oleh pelaku teror. Seruan jihad sebagai upaya pembenaran atas fikroh yang ditempuh. Padahal jihad memiliki arti yang sangat luas yaitu segala hal yang menunjukkan perilaku pejuang secara bersungguh-sungguh untuk melaksanakan ajaran agama. Jihad dapat diartikan sesuai dengan situasi sosial dan keadaan serta profesi seseorang. Dalam arti melaksanakan dengan sungguh apa yang menjadi tugas dan fungsi pokoknya; (3) Stigma bahwa Islam identik dengan kekerasan adalah sesat dan tidak dapat dibenarkan karena Islam sendiri dalam Al-Qur'an memberikan kebebasan bagi agama lain untuk beribadah sesuai agamanya. Islam bukanlah agama kekerasan, tetapi Islam sering dijadikan alat untuk meraih kekuasaan. Islam dijadikan sebagai komoditas politik untuk menggaet kekuasaan.

\section{DAFTAR PUSTAKA}

Agil Asshofie, Radikalisme Gerakan Islam, http://agil-asshofie.blogspot.com/2011/10 /radikalisme-gerakan-politik.html, diakses pada 10 April 2014.

Abu rokhmad, Pandangan Kiai Tentang Farhan Deradikalisasi Paham Islam Radikal Di Kota Semarang, Jurnal “Analisa” Volume 21 Nomor 01 Juni 2014 halaman 2737.h. 29-30.

Abu Alhasan Ali Al-Bashari Al-Mawardi, etika agama dan dunia, (Bandung: CV Pustaka Setia, 2002).

Afadlal, Islam dan Radikalisme di Indonesia, (Jakarta:LIPI, 2005).

Ahmad Baidowi, Prinsip Dakwah Tanpa Kekerasan dalam Al-Qur'an, Hermeneutik, Vol. 9, No.2, Desember 2015.

Ahmad Rizky Mardhatillah Umar, Melacak akar radikalisme Islam di Indonesia, Jurnal Ilmu Sosial dan Ilmu Politik Volume 14, Nomor 2, November 2010 (169-186) ISSN 1410-4946.

Ali Imron, Konsep Jihad Dan Implementasinya Terhadap Pembelajaran Di Madrasah (Studi Kasus Pada Madrasah Se-Kecamatan Karangawen, Kabupaten Demak 2014), Tesis STAIN Salatiga, Diakses Tanggal 03/07/2017 Jam 14.00 WITA.

Abu Abdullah Muhammad bin 'Ali bin al-Husain al-Hakim atTirmidzi, Nawâdir al Ushûl Fî Ahâdîts ar - Rasûl Shallallâhu 'Alaihi Wa Sallam , juz IV, hal. 56)

Dewan Redaksi, Ensiklopedi Islam 2, Fas-Kalangan, (Jakarta: Ichtiar Baru van Hoeve, 1994).

DadanRusmana, al Qur'an dan Hegemoni Wacana Islamologi Barat, cet. I.,(Bandung: Pustaka Setia, 2006).

Emna Laisa, islam dan radikalisme, Islamuna,Volume 1 Nomor 1 Juni 2014. 
H. Ma'mun Efendi Nur, Hukum Jihad dan Terorisme: Perspektif Al-Qur'an, Maslahah, Vol.1, No. 1, Juli 2010.

Junaidi Abdillah, Radikalisme Agama: Dekonstruksi Tafsir Ayat-Ayat "Kekerasan" Dalam Al-Qur'an, Volume 8, Nomor 2, Desember 2014 h. 282

M. Quraish Shihab, wawasan Al-Qur'an, Tafsir Maudhu' I atas pelbagai persoalan umat, (Bandung: Mizan, 1996), jet ke 3.

Maulani, Z.A. dkk., Islam dan Terorisme: dari Minyak Hingga Hegemoni Amerika. Cet. Ke (Yogyakarta: UCY Press, 2005).

M. Imdadun rahmat, “Arus Baru Islam Radikal” (Jakarta: Erlangga, 2005).

Nasution, Harun, Islam Rasional, (Bandung:Mizan, 1995).

Nuraida, Gerakan Radikalisme Di Indonesia, Wardah: No. 23/ Th. XXII/Desember 2011.

Quintan Wiktorowicz, Islamic Activism, A Social Movement TheoryApproach, Bloomington dan Indianapolis, IndianaUniversity Press, 2004, Book review oleh Noorhaidi Hasan.

Republika.co.id diakses tanggal 24/3/2017 jam 7.09

Sofwan, Ridin, "Para Wali Mengislamkan Tanah Jawa" dalamMerumuskan KembaliInterrelasi Islam-Jawa, (Yogyakarta: Gama Media, 2004).

Susiba dan Yasnel, Akidah Akhlak, (Pekan baru: CV Mutiara Pesisir Sumatra, 2014).

Sihab dalam Kamarudin, Jihad Dalam Perspektif Hadis, STAIN Datokarama Palu, Jl. Diponegoro 23 Palu.

Zainuddin Dan M Jamhari, Akidah Dan Ibadah, (Bandung: Pustaka Setia, 1999). 